\title{
INOVASI PEMBELAJARAN PAI DI MASA PANDEMI COVID-19
}

\author{
Kurniadin \\ Email : kurniagarsela74@gmail.com \\ Universitas Islam Al-Ihya Kuningan
}

\begin{abstract}
ABSTRAK
Pembelajaran PAI di sekolah menghadapi problematika sehingga memerlukan pembenahan secara teknis dan menuntut adanya inovasi dalam proses pembelajaran PAI di sekolah, ketika dunia dihadapkan dengan pandemi covid-19 yang melanda. Wabah Covid-19 memberikan dampak terhadap pembelajaran PAI di sekolah. Keadaan seperti ini memaksa guru PAI harus melakukan proses pembelajaran secara inovasi yang dapat mempengaruhi proses KBM serta tingkat perkembangan peserta didik dalam merespon materi yang disampaikan. Dengan inovasi, kreativitas dan usaha yang terus menerus, sehingga dapat menemukan cara-cara baru dan dapat menjadikan sesuatu yang lebih baik. "Problem Solving" Pembaharuan Pendidikan adalah upaya yang lebih diminati dan berkembang. Pemberian tugas atau latihan yang tepat, hakekatnya upaya seorang guru memberikan "peluang" bagi siswa untuk terjadi proses belajar dengan maksimal.
\end{abstract}

\section{Kata kunci: inovasi mengajar, pendidikan agama Islam, masa pandemi}

\section{ABSTRACT}

PAI learning in schools faces problems that require technical improvement and demands innovation in the PAI learning process in schools, when the world is faced with the Covid-19 pandemic that has hit. The Covid-19 outbreak has had an impact on Islamic Education learning in schools. This situation forces Islamic education teachers to carry out an innovative learning process that can affect the teaching and learning process and the level of development of students in responding to the material presented. With continuous innovation, creativity and effort, so that we can find new ways and can make something better. "Problem Solving" Educational reform is an effort that is more desirable and growing. Giving the right assignment or training, essentially the efforts of a teacher provide "opportunities" for students to take place in the maximum learning process.

Keywords: teaching innovation, Islamic religious education, pandemic period 


\section{PENGANTAR}

Pandemi COVID-19 merupakan musibah yang memilukan seluruh penduduk bumi. Seluruh segmen kehidupan manusia di bumi terganggu, tanpa kecuali pendidikan. Banyak negara memutuskan menutup sekolah, perguruan tinggi maupun universitas, termasuk Indonesia. Ada dampak bagi keberlangsungan pendidikan yang disebabkan oleh pandemi Covid-19 menjadi pandemik global yang penyebarannya begitu menghawatirkan dan akhirnya pemerintah mengeluarkan kebijakan agar seluruh warga masyarakat untuk melakukan social distancing atau menjaga jarak, termasuk dalam bidang pendidikan.

Tentunya berdampak pula pada kualitas pembelajaran PAI, siswa dan guru yang sebelumnya berinteraksi secara langsung dalam ruang kelas sekarang harus berinteraksi dalam ruang virtual yang terbatas. Guru PAI dituntut memberikan pengajaran yang baik, menciptakan suasana yang kondusif untuk belajar dan secara kreatif dan inovatif menggunakan media belajar yang menarik agar siswa dapat memahami materi pembelajaran dan tujuan pembelajaran dapat tercapai. Selain itu, motivasi belajar siswa juga berpengaruh dalam keberhasilan pembelajaran PAI.

Adapun metode penelitian yang dipakai adalah metode kualitatif dengan jenis penelitian lapangan (flied Research). Dengan teknik pengumpulan data menggunakan wawancara serta dokumentasi. Sumber data utama dalam penelitian ini adalah siswa SMK dan Guru PAI SMK. Fokus penelitiannya yakni proses pembelajaran PAI pada masa covid-19 yang dilakukan oleh guru PAI di sekolah.

Dapat kita lihat betapa gembiranya anak-anak saat pembelajaran tatap muka di sekolah, untuk itu perlu dipikirkan inovasi dalam pembelajaran di masa pandemi khususnya untuk materi Pendidikan Agama Islam. Untuk menyelenggarakan pendidikan yang menyenangkan bagi anak sehingga anak bisa berprestasi ada tiga $\mathrm{C}$ yang harus diperhatikan, yaitu children (anak), content (materi), dan context (situasi). Lebih lanjut Risman menjelaskan perlakuan yang tepat dan materi yang sesuai tidak akan mempunyai efek yang positif jika tidak disampaikan pada situasi (context) yang tepat. (Hairunisa et al., n.d.) 


\section{PEMBAHASAN}

Pandemi Covid-19 berlangsung sampai saat ini hampir 1 tahun, dengan wabah yang berkepanjangan berdampak pada juataan pelajar tidak terkecuali di Indonesia. Dampak yang paling mendasar bagi siswa yaitu penutupan sekolah, penundaan penilaian yang berakibat penurunan motivasi belajar bagi para siswa, hal ini serupa dan nyata dialami pada pembelajaran Pendidikan Agama Islam.

Iklim belajar yang diciptakan pembelajaran daring turut mempengaruhi motivasi belajar siswa, jika dalam pembelajaran luring guru mampu menciptakan suasana kelas kondusif untuk menjaga motivasi belajar siswa agar pembelajaran dapat tercapai karena iklim kelas memiliki pengaruh yang signifikan dengan motivasi belajar. Namun kondisi pembelajaran daring menyebabkan guru kesulitan untuk mengontrol dan menjaga iklim belajar karena terbatas dalam ruang virtual. Kondisi ini menyebabkan motivasi belajar siswa dapat menurun bahkan mempengaruhi hasil belajar siswa.(A. Cahyani, I. D. Listiana, S. Puteri, 2020). Oleh karena itu motivasi belajar sangat penting untuk dimiliki oleh setiap siswa, baik motivasi intrinsik maupun ekstrinsik. Keadaan belajar luring bisa mempengaruhi meningkatnya motivasi belajar siswa, pada pembelajaran luring pengajar mampu membangun suasana kelas aman buat menjaga motivasi belajar peserta didik agar pembelajaran bisa tercapai sebab situasi kelas mempunyai pengaruh yang signifikan dengan motivasi belajar. Sedangkan pembelajaran daring mengalami motivasi belajar siswa bisa menurun bahkan mensugesti akibat belajar peserta didik dan merasa jenuh dengan keadaan.

Dengan menggunakan metode daring dari berbagai aplikasi pembelajaran untuk pembelajaran PAI bukan tanpa masalah, banyak varians masalah yang menghambat terlaksananya efektivitas pembelajaran dengan metode daring banyak diantaranya: keterbatasan penguasaana atau pemahaman teknologi baik siswa maupun guru, sarana prasarana kurang memadai, jaringan internet. 


\section{Pendidikan Agama Islam}

Mata pelajaran Pendidikan Agama Islam merupakan mata pelajaran yang tidak kalah pentingnya dengan mata pelajaran lain bagi peserta didik karena didalam PendidikanAgama Islam mencakup bahan-bahan pendidikan agama berupa kegiatan, atau pengetahuan dan pengalaman serta nilai atau norma-norma dan sikap atau karakter serta budi pekerti siswa.

Pendidikan Agama Islam mempunyai tujuan yang bagus dan baik diharapkan mampu menjalin Ukhuwah Islamiah seperti yang diharapkan dan menghargai satu sama lain atau dengan agama lain, suku, ras dan tradisi yang berbeda-beda agar terciptanya kerukunan. Dan juga terciptanya kebersamaan atau hidup bertoleransi.(Heri Gunawan, 2019). Tujuan berikut adalah mempersiapkan perkembangan anak agar mampu berperan serta secara berkesinambungan dalam pembangunan manusia yang berkembang terus dan mampu beramal kebajikan selama dalam upaya mencari kebahagiaan di dunia dan akhiratnya. Dengan demikian tujuan pendidikan Islam adalah yang dapat memberikan perkembangan atau kepentingan bagi peserta didik.(Daulay, 2014). Dari kedua tujuan pembelajaran PAI tersebut alangkah sangat pentingnya pembelajaran PAI bagi peserta didik, karena PAI akan mencetak peserta didik yang berkarakter baik yang berakhlakul karimah dimasa yang akan datang dan mampu menghadapi kemajuan zaman dengan baik.

\section{Inovasi Pembelajaran PAI}

Inovasi adalah sebuah pembahruan yang bisa berupa ide, objek, produk, karya dan lainlain. Yang mana dengan menggembangkan atau menggabungkan hal yang sudah ada hingga terlihat baru. Sedangkan proses pembelajaran adalah sebuah kegiatan yang dilakukan oleh guru dan peserta didik atau individu maupun kelompok dalam belajar. Jadi, Inovasi pembelajaran adalah sebuah kegiatan belajar yang dilakukan oleh guru dan peserta didik atau individu dan kelompok dengan cara baru atau inovatif dalam proses belajar.(Aditia, 2020). Secara sederhana inovasi diartikan sebagai pembaruan atau pembahasan dengan ditandai adanya hal-hal yang baru. Upaya untuk mewujudkan halhal yang baru. Upaya untuk mewujudkan hal-hal yang baru tersebut adalah sangat 
dipengaruhi oleh beberapa hal antara lain dalam upaya pemecahan masalah yang dihadapi seseorang atau kelompok orang.(Iriainsyah, 2020)

Hakikat inovasi pembelajaran adalah ide, gagasan baru tentang berbagai faktor yang dapat mendorong terjadinya pembelajaran yang lebih baik dan tepat guna. Secara harfiah inovasi pembelajaran dapat disebut pembaharuan pembelajaran. Inovasi pembelajaran bagian dari inovasi pendidikan, yaitu usaha-usaha dengan melakukan perubahan untuk mencapai suatu yang lebih baik dalam bidang Pendidikan.(Febriandi, 2020)

Pembelajaran PAI yang berkualitas sangat tergantung dari motivasi peserta didik dan inovasi serta kreativitas pendidik. Peserta didik yang memiliki motivasi tinggi ditunjang dengan pendidik yang mampu memfasilitasi motivasi tersebut akan membawa pada keberhasilan pencapaian target belajar. Desain pembelajaran PAI yang baik, ditunjang fasilitas yang memandai, ditambah dengan kreativitas dan innovasi dari pendidik akan membuat peserta didik lebih mudah mencapai target belajar.

Selain kemampuan teknologi, guru harus mampu berinovasi dalam pembelajaran, mengembangkan metode, strategi, model, dan media sesuai karakteristik dan kebutuhan siswa.(Ely Novianti, 2020). Hal itulah menjadi peluang bagi guru khususnya PAI untuk mengembangkan dalam metode pembelajaran jarak jauh. Kemudian dalam pembelajaran guru perlu lebih kreatif dan inovatif dalam mengeksplor aktivitas belajar mengajar.(Ely Novianti, 2020).

Jadi yang harus dilakukan oleh Guru PAI dalam upaya inovasi pembelajaran antara lain menggubah pola pembelajaran tatap muka menjadi pola pembelajaran tanpa tatap muka atau sistem pembelajaran jarak jauh (PJJ/Daring) dengan cara dapat memanfaatkan teknologi informasi, bisa dalam bentuk e-learning, atau aplikasi-aplikasi yang memudahkan penyampaian materi pembelajaran, sehingga proses pembelajaran semakin menarik dan tidak membosankan, contoh inovasi dalam pembelajaran al-Qur'an Hadis bentuk pembelajaran Web Enhance Course atau pemanfaatan web blog dan media games dalam pembelajaran. Model pembelajaran yang bisa digunakan oleh Guru PAI sebagai media penyampaian ilmu pengetahuan, yaitu pembelajaran daring dan 
pembelajaran campuran (kombinasi dari dua metode pembelajaran yaitu tatap muka dan pembelajaran daring). Dengan kata lain, model pembelajaran merupakan bungkus atau bingkai dari penerapan suatu pendekatan, metode, dan teknik pembelajaran. Metode pembelajaran daring tidak menuntut siswa untuk hadir di kelas. Siswa dapat mengakses pembelajaran melalui media internet. Strategi yang digunakan dengan pendekatan contextual learning, dapat juga dengan modul pembelajaran aktif, kreatif, efektif, dan menyenangkan (PAKEM. Guru tidak membebankan murid dalam tugas-tugas yang dihantarkan dalam belajar di rumah. Jika perlu guru hadir secara gagasan dalam door to door peserta didik. 


\section{KESIMPULAN}

Adanya wabah COVID-19 yang mengharuskan proses pembelajaran dilakukan secara daring menuntut adanya penyesuaian baik yang harus dilakukan oleh pendidik maupun oleh peserta didik. Pembelajaran jarak jauh juga memberikan tantangan dan peluang bagi guru PAI untuk memberikan pengajaran dengan memanfaatkan teknologi sehingga terpacu untuk mempelajarinya.

Inovasi pembelajaran PAI dapat diwujudkan apabila guru PAI mampu berinovasi melek teknologi bahkan menguasai untuk dimanfaatkan dalam aktivitas proses pembelajaran. Inovasi model pembelajaran PAI sebagai media penyampaian ilmu pengetahuan, yaitu pembelajaran daring dan pembelajaran campuran (kombinasi dari dua metode pembelajaran yaitu tatap muka dan pembelajaran daring) Dengan kata lain, model pembelajaran merupakan bungkus atau bingkai dari penerapan suatu pendekatan, metode, dan teknik pembelajaran. Inovasi Metode pembelajaran daring tidak menuntut siswa untuk hadir di kelas. Siswa dapat mengakses pembelajaran melalui media internet. Inovasi strategi pembelajaran PAI yang digunakan dengan pendekatan contextual learning, dapat juga dengan modul pembelajaran aktif, kreatif, efektif, dan menyenangkan. Guru tidak membebankan murid dalam tugas-tugas yang dihantarkan dalam belajar di rumah. 


\section{REFERENSI}

A. Cahyani, I. D. Listiana, S. Puteri, and L. (2020). Fandemi Covid-19. Motivasi Belajar Siswa SMA Pada Pembelajaran Daring Di Masa Pandemi Covid-19, 3(01), 123-140.

Aditia, S. (2020). Inovasi Pembelajaran Berbasis Aplikasi Mobile Pada Masa Pandemi Covid-19.

Daulay, M. (2014). Inovasi Pendidikan Islam Muhammad Abduh. Darul Ilmi, 1(02), 77-101. http://jurnal.iain-padangsidimpuan.ac.id/index.php/DI/article/view/238

Ely Novianti. (2020). Analisis Kebijakan Pembelajaran Pai Di Masa Pandemi: Peluang Dan Tantangan. Jurnal Pendidikan Islam, 11(2), 201-212.

Febriandi. (2020). Pembelajaran Daring di Masa Fandemi Covid-19 Pembelajaran Olah Vokal Di Prodi Seni Pertunjukan Universitas Tanjungpura Pontianak, 28(2), 1-43.

Hairunisa, Utami, S., \& Asran, M. (n.d.). PENINGKATAN AKTIVITAS PEMBELAJARAN PKn MENGGUNAKAN METODE BERMAIN PERAN PADA SISWA KELAS V SD.

Heri Gunawan, Kurikulum dan Pembelajaran Pendidikan Agama Islam, (Bandung:, \& Alfabeta, 2013. (2019). Journal of Chemical Information and Modeling, 53(9), 1689-1699.

Iriainsyah, H. S. (2020). Membangun Kreativitas Guru dengan Inovasi Pembelajaran. Pendidikan STKIP Kusuma Negara II, 1, 1-6. 